\title{
Spawanie złączy doczołowych jedno- i różnoimiennych ze stali Tempaloy A-3
}

\author{
Experience in welding of similar and dissimilar \\ butt joints made of Tempaloy A-3 steel
}

\section{Streszczenie}

Dynamiczny rozwój stali stosowanych w energetyce na elementy kotłów o parametrach nadkrytycznych wywołuje nowe wyzwania spawalnicze. Wprowadzanie nowych kombinacji dodatków stopowych w celu osiągnięcia jak najlepszych właściwości mechanicznych, w tym odporności na pełzanie, nie pozostaje bez wpływu na spawalność nowych stali. Każda z nich musi przejść wiele prób, szczególnie w zakresie gięcia i spawania, żeby można było opracować technologie umożliwiające wykonanie oraz montaż instalacji kotłowych. Stale martenzytyczne o zawartości $9 \% \mathrm{Cr}$, przeznaczone na przegrzewacze pary, odznaczają się dobrą wytrzymałością na pełzanie i niską odpornością na utlenianie $w$ temperaturze powyżej $600^{\circ} \mathrm{C}$. Natomiast stale o zawartości $12 \%$ Cr charakteryzują się zdecydowanie lepszą odpornością na utlenianie, lecz ich wytrzymałość w podwyższonej temperaturze spada - stosowanie ich na elementy kotłów pracujących przy najwyższych parametrach jest ograniczone.

Lukę między tymi stalami bardzo dobrze uzupełniają stale austenityczne, których wytrzymałość na pełzanie i odporność na utlenianie są niekwestionowane. W artykule zaprezentowano doświadczenia zdobyte podczas spawania połączeń jednorodnych stali Tempaloy A-3 oraz połączeń mieszanych stali Tempaloy A-3 ze stalą T91 z wykorzystaniem EPRI87.

\section{Wstęp}

Obecny trend do obniżenia kosztów wytwarzania energii jest związany ze zwiększaniem sprawności bloków energetycznych w elektrowniach

Mgr inż. Robert Jachym, mgr inż. Krzysztof Kwieciński, dr hab. inż. Mirosław Łomozik, prof. IS - Instytut Spawalnictwa, Gliwice, dr inż. Michał Urzynicok - ZELKOT.

\section{Abstract}

The dynamic development of steels used in the power industry for boiler elements with supercritical parameters results with new challenges in welding. Introduction of ever new combinations of alloying elements to achieve the best mechanical properties, including creep resistance, does not remain without effect on the weldability of new steel. Each of them has to go through many tests, especially when it comes to bending and welding so as to be able to develop technologies to enable seamless execution and installation of boilers. Martensitic steels containing $9 \% \mathrm{Cr}$, designed for steam superheaters, exhibit good creep resistance, while a low resistance to oxidation at temperatures above $600^{\circ} \mathrm{C}$. Steels with $12 \% \mathrm{Cr}$ have a much better resistance to oxidation, but unfortunately, their strength at elevated temperatures drop and hence their use for boiler components operating at the highest performance is limited.

The gap between the above steels complement very well austenitic steels where creep and oxidation resistance are unquestionable. This article presents the experience gained during the welding of similar joints made of Tempaloy A-3, and dissimilar joints made of Tempaloy A-3 with T91 steel using EPRI87 material.

konwencjonalnych. Wzrost sprawności może być uzyskany wskutek zwiększenia kluczowych parametrów technologicznych, czyli ciśnienia oraz temperatury pary. Osiągnięcie wyższych parametrów kotłów parowych możliwe jest obecnie jedynie dzięki zastosowaniu nowoczesnych materiałów konstrukcyjnych, które mogą przenieść zadawane obciążenia użytkowe oraz zapewnić wystarczająco wysoką żaroodporność w podwyższonej temperaturze.

Nowoczesne stale martenzytyczne, takie jak P92 (X10CrWMoVNb9-2), VM12 (X12CrCoWVNb12-2-2) 
czy PB2 (X12CrMoCoVNbNB9-2-1), pozwalają na projektowanie instalacji elektrowni, w których temperatura pary przegrzanej wynosi $625^{\circ} \mathrm{C}$. Zwiększenie ciśnienia oraz temperatury pary ma bezpośredni wpływ na warunki pracy elementów kotłów, a przede wszystkim przegrzewaczy pary. Stale martenzytyczne charakteryzują się bardzo dobrą wytrzymałością na pełzanie i niską odpornością na utlenianie w wysokiej temperaturze (P92, PB2) albo odwrotnie (VM12), dlatego rozwój nowoczesnych stali ukierunkowany został na materiały

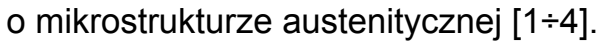

W wyniku długoletnich badań powstały dwa gatunki stali opracowanej przez Tenaris NKK Tubes: Tempaloy AA-1 oraz Tempaloy A-3. Analiza spawalności tego drugiego gatunku stali jest przedmiotem niniejszego artykułu.

\section{Charakterystyka badanych stali}

Stal Tempaloy A-3 jest stalą austenityczną o zawartości $22 \% \mathrm{Cr}$ i $15 \% \mathrm{Ni}$, której mikrostruktura nie zawiera ferrytu delta. Czynnikami, które bezpośrednio wpływają na wytrzymałość na pełzanie, są węglikoazotki niobu $\mathrm{Nb}(\mathrm{C}, \mathrm{N})$ występujące zarówno bezpośrednio w ziarnach, jak i po granicach ziaren, oraz azotki chromu i niobu CrNbN, które występują w stali już w stanie dostawy.

Podczas pracy, w zakresie temperatury $600 \div 750^{\circ} \mathrm{C}$, mikrostruktura stali umacnia się przez węgliki $\mathrm{M}_{23} \mathrm{C}_{6}$, tworząc fazę $\sigma$ oraz wydzielenia fazy $\Delta$, składające się głównie $z$ azotków niobu i chromu.

Na odporność na pełzanie stali Tempaloy A-3 wpływają głównie węgliki chromu $\mathrm{Cr}_{23} \mathrm{C}_{6}$ rozlokowane po granicach ziaren oraz wydzielenia fazy $\Delta$, które skutecznie blokują ruch dyslokacji. Nawet po długotrwałej eksploatacji w bardzo wysokiej temperaturze wydzielenia fazy $\Delta$ nie ulegają rozrostowi i umożliwiają efektywne blokowanie ruchu dyslokacji [5].

Wysoka odporność korozyjna oraz odporność na utlenianie jest uwarunkowana wysoką zawartością chromu i zarówno w środowisku spalin, jak i popiołu kotłowego w temperaturze $700^{\circ} \mathrm{C}$, jest o ok. $20 \%$ wyższa niż dla stali austenitycznej TP321H, natomiast odporność na utlenianie w temperaturze $750^{\circ} \mathrm{C}$ jest ok. pięciokrotnie wyższa od dla stali TP321H.

\section{Przedmiot badań}

Przedmiotem badań była rura o średnicy zewnętrznej $38 \mathrm{~mm}$ i grubości ścianki $8,8 \mathrm{~mm}$ ze stali Tempaloy A-3. Skład chemiczny stali przedstawiono w tablicy I. Rura była spawana metodą TIG (141) w pozycji PF.

Właściwości mechaniczne stali Tempaloy A-3 w stanie wyjściowym zamieszczono w tablicy II.

Do wykonania połączenia mieszanego została zastosowana rura o średnicy zewnętrznej $38 \mathrm{~mm}$
Tablica I. Skład chemiczny stali Tempaloy A-3 wg świadectwa jakości producenta

Table I. Chemical composition of Tempaloy A-3 steel acc. to producer data

\begin{tabular}{|c|c|c|c|c|c|c|c|}
\hline \multicolumn{1}{|c|}{ Zawartość pierwiastków, \% } \\
\hline $\mathrm{C}$ & $\mathrm{Si}$ & $\mathrm{Mn}$ & $\mathrm{Cr}$ & $\mathrm{Ni}$ & $\mathrm{B}, \mathrm{ppm}$ & $\mathrm{N}, \mathrm{ppm}$ & $\mathrm{Nb}$ \\
\hline 0,05 & 0,28 & 1,38 & 21,9 & 15,61 & 21 & 1596 & 0,62 \\
\hline
\end{tabular}

Tablica II. Właściwości mechaniczne stali Tempaloy A-3 wg świadectwa jakości producenta.

Table II. Mechanical properties of Tempaloy A-3 steel acc. to producer data

\begin{tabular}{|c|c|c|c|}
\hline \multicolumn{4}{|c|}{ Właściwości mechaniczne } \\
\hline $\mathrm{R}_{\mathrm{e}}, \mathrm{MPa}$ & $\mathrm{R}_{\mathrm{m}}, \mathrm{MPa}$ & $\mathrm{A}_{\min }, \%$ & $\mathrm{HV}$ \\
\hline 537 & 780 & 41 & 188 \\
\hline
\end{tabular}

Tablica III. Skład chemiczny stali T91 wg świadectwa jakości producenta

Table III. Chemical composition of T91 steel acc. to producer data

\begin{tabular}{|c|c|c|c|c|c|c|c|c|}
\hline \multicolumn{10}{|c|}{ Zawartość pierwiastków, \% } \\
\hline $\mathrm{C}$ & $\mathrm{Si}$ & $\mathrm{Mn}$ & $\mathrm{Cr}$ & $\mathrm{Mo}$ & $\mathrm{Ni}$ & $\mathrm{V}$ & $\mathrm{Nb}$ & $\mathrm{N}$ \\
\hline 0,1 & 0,35 & 0,44 & 8,25 & 0,94 & 0,21 & 0,21 & 0,06 & 0,044 \\
\hline
\end{tabular}

Tablica IV. Właściwości mechaniczne stali T91 wg świadectwa jakości producenta.

Table IV. Mechanical properties of T91 steel acc. to producer data

\begin{tabular}{|c|c|c|}
\hline \multicolumn{3}{|c|}{ Właściwości mechaniczne } \\
\hline $\mathrm{R}_{\mathrm{e}}, \mathrm{MPa}$ & $\mathrm{R}_{\mathrm{m}}, \mathrm{MPa}$ & $\mathrm{A}_{\text {min. }}, \%$ \\
\hline 548 & 697 & 19,9 \\
\hline
\end{tabular}

i grubości ścianki $7,1 \mathrm{~mm}$ ze stali X10CrMoVNb9-1 (T91), której skład chemiczny podano $w$ tablicy III. Rura ta również była spawana metodą TIG w pozycji PF. Po spawaniu złącze poddano wyżarzaniu odprężającemu w temperaturze $760^{\circ} \mathrm{C}$ przez $30 \mathrm{~min}$.

Właściwości mechaniczne stali X10CrMoVNb9-1 (T91) w stanie wyjściowym przedstawiono w tablicy IV.

\section{Materiał dodatkowy do spawania stali Tempaloy A-3 (połączenie jednoimienne)}

O doborze materiału dodatkowego do spawania decyduje skład chemiczny materiału rodzimego i warunki pracy połączeń. Materiały powinny zapewnić skład chemiczny spoiny i jej właściwości mechaniczne jak najbardziej zbliżone do właściwości materiału rodzimego.

Jedynym, aktualnie dostępnym materiałem dodatkowym do spawania stali Tempaloy A-3 jest drut lity firmy Kobelco o oznaczeniu TGS-3A. Na ten drut nie uzyskano atestu, zatem brakuje informacji na temat jego składu chemicznego oraz właściwości wytrzymałościowych. 


\section{Materiał dodatkowy do spawania stali Tempaloy A-3 ze stalą T91 (połączenia różnoimienne)}

Materiał dodatkowy EPRI 87 został zaprojektowany z myślą o wykonywaniu połączeń mieszanych pomiędzy stalami martenzytycznymi, takimi jak T91/T92, oraz stalami austenitycznymi, np. Super $304 \mathrm{H}$ i gatunkami serii Tempaloy.

Wcześniej stosowane materiały na bazie niklu (np. IN82) powodowały występowanie strefy zubożonej $\mathrm{w}$ węgiel (tzw. white zone), natomiast użycie $\mathrm{np}$. stopu IN617 było ekonomicznie nieuzasadnione, a dodatkowo po spawaniu w złączach występowały mikropęknięcia.

Ze względu na optymalnie dobrany skład chemiczny drutu EPRI 87, w połączeniach mieszanych praktycznie nie występuje strefa odwęglona. Aby ograniczyć rozszerzalność cieplną metalu spoiny, zmniejszono zawartość manganu poniżej $2 \%$, natomiast mikropęknięcia wyeliminowano przez optymalizację zawartości niobu i węgla wg zależności $\mathrm{Nb}: \mathrm{C}>10$ [6]. W tablicy V podano skład chemiczny prętów litych EPRI87 produkowanych przez firmę Metrode.

Tablica V. Skład chemiczny zastosowanego spoiwa wg danych producenta

Table V. Chemical composition of filler metal acc. to producer data

\begin{tabular}{|l|c|c|c|c|c|c|c|c|}
\hline \multirow{2}{*}{ Gatunek } & \multicolumn{7}{|c|}{ Zawartość pierwiastków, \% } \\
\cline { 2 - 9 } & $\mathrm{C}$ & $\mathrm{Mn}$ & $\mathrm{Si}$ & $\mathrm{Cr}$ & $\mathrm{Ni}$ & $\mathrm{Mo}$ & $\mathrm{Nb}$ & $\mathrm{Fe}$ \\
\hline EPRI 87 & 0,11 & 1,55 & 0,16 & 8,52 & reszta & 2,02 & 1,09 & 38,8 \\
\hline
\end{tabular}

\section{Plan badań}

W ramach badań zaplanowano wykonanie złączy jednoimiennych ze stali Tempaloy A-3 spawanych drutem litym Kobelco TGS-3A oraz połączeń różnoimiennych stali Tempaloy A-3 ze stalą T91 spawanych prętami litymi Metrode EPRI 87.

Po wykonaniu złączy spawanych przeprowadzono badania nieniszczące, tj.: VT, PT i RT. Badania te wykonano $z$ uwzględnieniem poziomu jakości $B$ wg PN-EN ISO 5817 [7]. Po uzyskaniu pozytywnych wyników badań NDT ze złączy zostały pobrane próbki do badań niszczących.

Zakres badań niszczących obejmował statyczną próbę rozciągania złącza spawanego, próbę zginania, badania udarności, badania metalograficzne makroi mikroskopowe oraz pomiary twardości.

\section{Badania wytrzymałości na rozciąganie}

Badania wykonano w celu określenia wytrzymałości złącza spawanego na rozciąganie $\left(R_{m}\right)$ oraz weryfikacji uzyskanych wyników ze względu na wymaganą

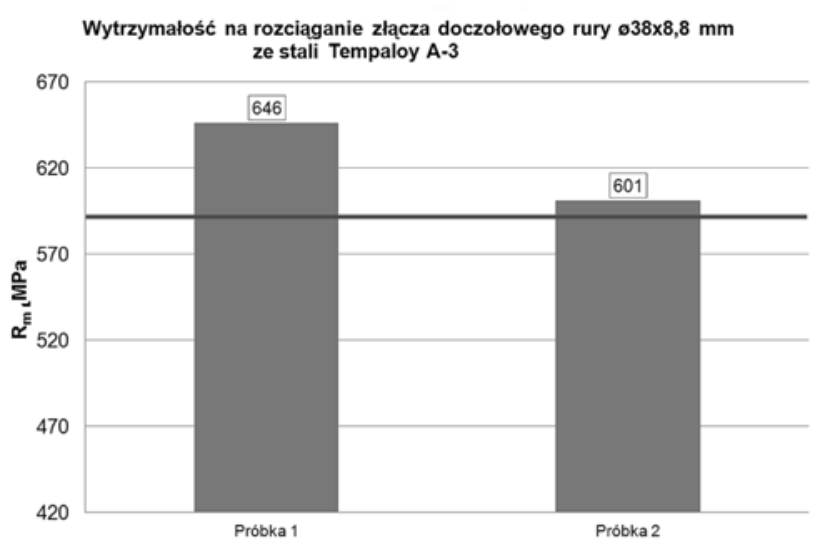

Rys. 1. Wytrzymałość na rozciąganie złącza doczołowego rury $ø 38 \times 8,8 \mathrm{~mm}$ ze stali Tempaloy A-3

Fig. 1. Tensile strength of $ø 38 \times 8,8 \mathrm{~mm}$ Tempaloy A-3 steel tube butt welds

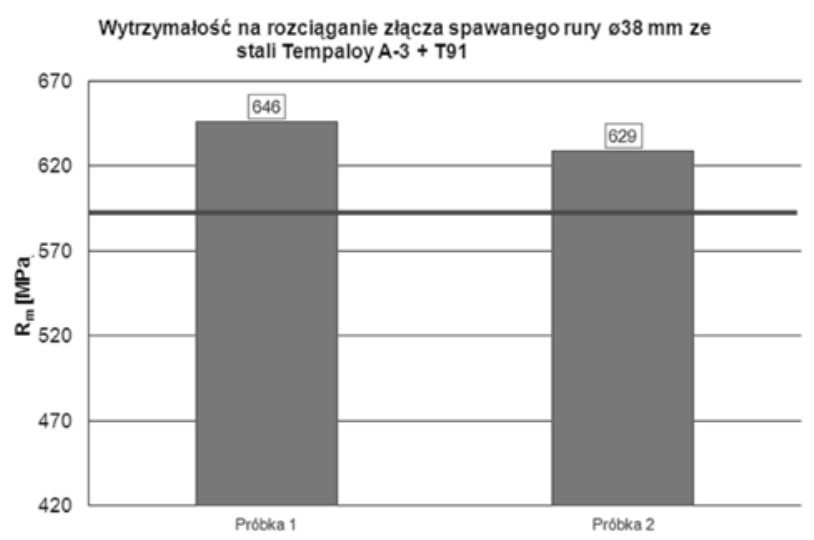

Rys. 2. Wytrzymałość na rozciąganie złącza doczołowego niejednorodnego rury ø38 mm ze stali Tempaloy A-3 oraz T91

Fig. 2. Tensile strength of $ø 38 \times 8,8 \mathrm{~mm}$ Tempaloy A-3 and T91 steel tube butt welds

minimalną wartość $R_{m}$ dla materiału rodzimego (MR), która wynosi $590 \mathrm{MPa}$ dla stali Tempaloy A-3 (określona przez ASTM) oraz $630 \mathrm{MPa}$ dla stali T91 (określona przez EN 10216-2 [8]). Wartość minimalną zaznaczono na wykresie grubą linią (rys. 1, 2). Statyczną próbę rozciągania wykonano zgodnie $z$ wymaganiami PN -EN ISO 6892-1 [9] za pomocą maszyny wytrzymałościowej Instron 4210, wyposażonej w system komputerowego sterowania, rejestracji i zapisu wyników badań na próbkach wykonanych zgodnie z PN-EN ISO 4136:2011 [10].

\section{Próba udarności spoiny i SWC}

Badania wykonano w celu określenia wartości pracy łamania spoiny i SWC. Kryterium zamieszczone w PN-EN 12952-6 [11] określa minimalną wartość pracy łamania próbek o przekroju normalnym $(10 \times 10 \mathrm{~mm})$ w SWC na poziomie $24 \mathrm{~J}$ w temperaturze otoczenia, natomiast PN-EN 10216-2 [8] określa minimalną wartość pracy łamania dla MR na poziomie $27 \mathrm{~J}$. Wartości te zaznaczono na wykresach linią pogrubioną (rys. 3 i 4).

Uzyskane wyniki pracy łamania $w$ spoinie i SWC są wyższe od wartości wymaganych przez normy. Badania zostały przeprowadzone na próbkach 


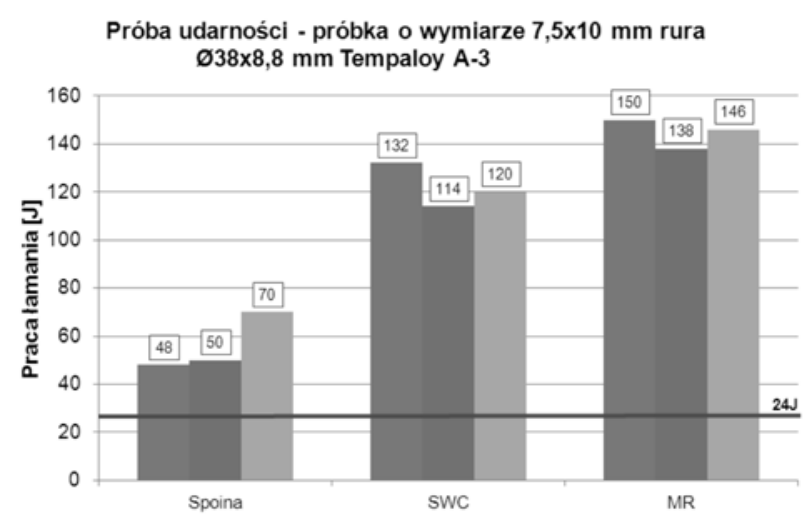

Rys. 3. Praca łamania spoiny, SWC i materiału rodzimego w złączach doczołowych rury $ø 38 \times 8,8 \mathrm{~mm}$ ze stali Tempaloy A-3

Fig. 3. Nominal KV energy for weld, HAZ and base metal in butt weIds of $\varnothing 38 \times 8,8 \mathrm{~mm}$ Tempaloy A-3 and T91 steel tubes

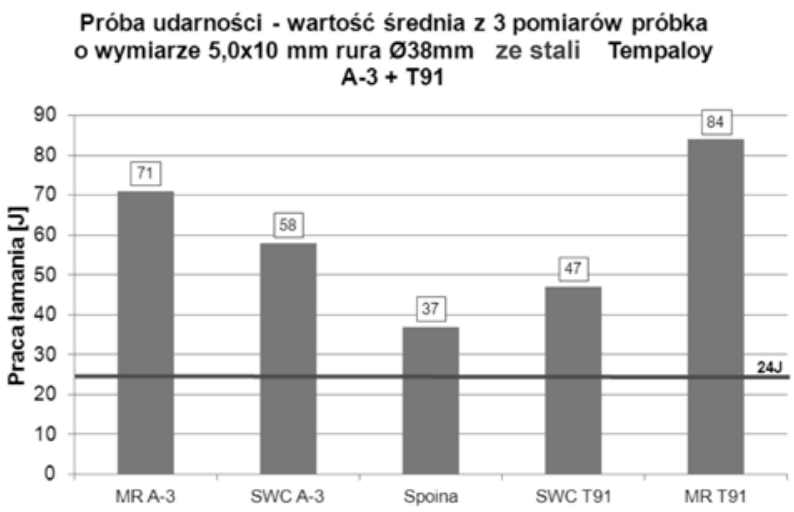

Rys. 4. Praca łamania spoiny, SWC i materiału rodzimego złącza doczołowego niejednorodnego rury $ø 38 \mathrm{~mm}$ ze stali Tempaloy A-3 oraz T91

Fig. 4. Nominal KV energy for weld, $\mathrm{HAZ}$ and base metal in dissimilar butt welds of $ø 38 \times 8,8 \mathrm{~mm}$ Tempaloy A-3 and T91 steel tubes

o zmniejszonym przekroju $(7,5 \times 10 \mathrm{~mm}$ - złącza jednoimienne, $5 \times 10 \mathrm{~mm}$ - złącza różnoimienne), dlatego wartości przedstawione na rysunkach są proporcjonalnie wyższe. Na rysunku 4 przedstawiono wartości średnie z trzech pomiarów.

Badania udarnościowe wykonano w temperaturze $+20^{\circ} \mathrm{C}$ na próbkach $z$ naciętym karbem Charpy'ego $\checkmark \mathrm{w}$ spoinie, linii wtopienia oraz w strefie wpływu ciepła zgodnie z wymaganiami PN-EN ISO 9016 [12] i PN-EN 10045-1:1994 [13].

\section{Póba zginania}

Próbę zginania $z$ rozciąganiem lica i grani spoiny wykonano zgodnie z PN-EN 15614-1 [14] i PN-EN ISO 5173 [15]. Według postanowień PN-EN 15614-1, kryterium próby jest uzyskanie kąta gięcia $180^{\circ}$, bez wystąpienia rys i pęknięć na rozciąganej powierzchni próbki. Uzyskane podczas badań wyniki spełniają wymagania normy (rys. 5 i 6 ).

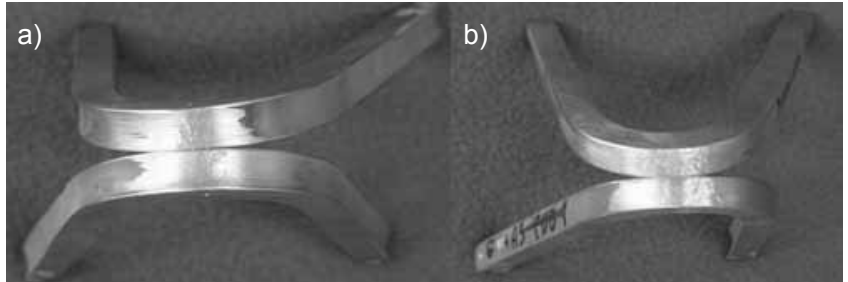

Rys. 5. Wyniki próby zginania rury $ø 38 \times 8,8 \mathrm{~mm}$ ze stali Tempaloy A-3: a) od strony grani, b) od strony lica

Fig. 5. $ø 38 \times 8,8 \mathrm{~mm}$ Tempaloy A-3 steel tubes butt weld bending test results: a) root of weld, b) face of weld

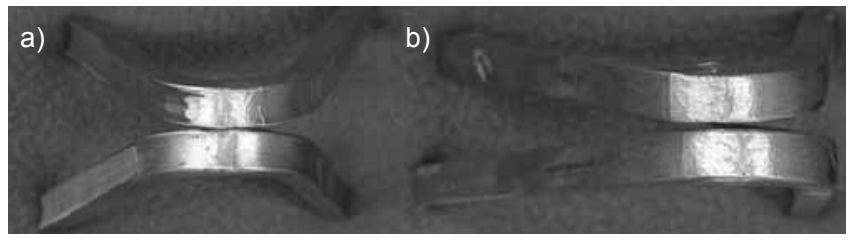

Rys. 6. Wyniki próby zginania złącza doczołowego niejednorodnego rury ø38 mm ze stali Tempaloy A-3 oraz T91: a) od strony grani, b) od strony lica

Fig. 6. $ø 38 \times 8,8 \mathrm{~mm}$ Tempaloy A-3 and T91 steel tubes butt weld bending test results: a) root of weld, b) face of weld

\section{Wyniki pomiarów twardości złączy spawanych}

Pomiary twardości wykonano zgodnie z PN-EN 15614-1 [14] i PN-EN 12952-6 [11]. Pomiary twardości dla stali austenitycznych nie są wymagane, zostały

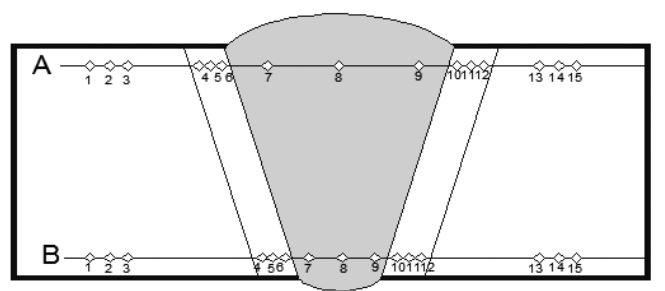

Rys. 7. Rozmieszczenie punktów pomiarów twardości w złączach spawanych

Fig. 7. Distribution of hardness measurements points in welded joints

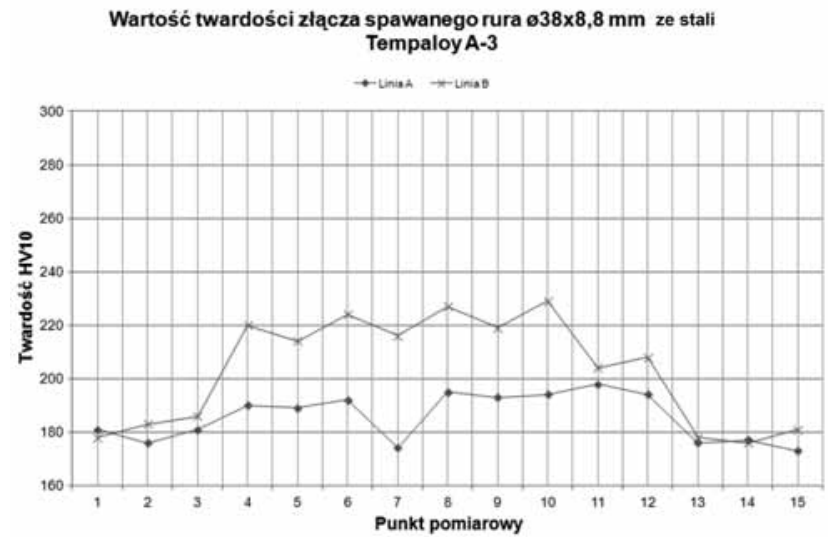

Rys. 8. Wyniki pomiarów twardości złącza doczołowego obwodowego ze stali Tempaloy A-3

Fig. 8. Hardnes distribution in circumferential butt weld of Tempaloy A-3 steel 


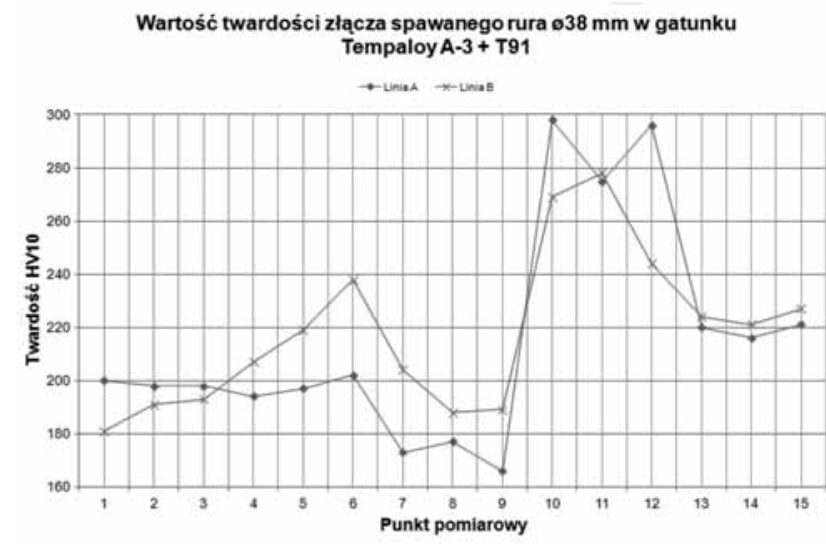

Rys. 9. Wyniki pomiarów twardości niejednorodnego złącza doczołowego obwodowego ze stali Tempaloy A-3 i T91

Fig. 9. Hardness distribution in dissimilar circumferential butt weld of Tempaloy A-3 and T91 steel

wykonane tylko w celach poznawczych. Wymienione normy definiują maksymalną twardość dla stali martenzytycznych na poziomie 350 HV10.

Schematyczne rozmieszczenie linii i punktów pomiarowych twardości przedstawiono na rysunku 7 , a wyniki pomiarów dla złącza jednorodnego ze stali Tempaloy A-3 i złącza niejednorodnego ze stali Tempaloy A-3 i T91 zamieszczono na rysunkach 8 i 9.

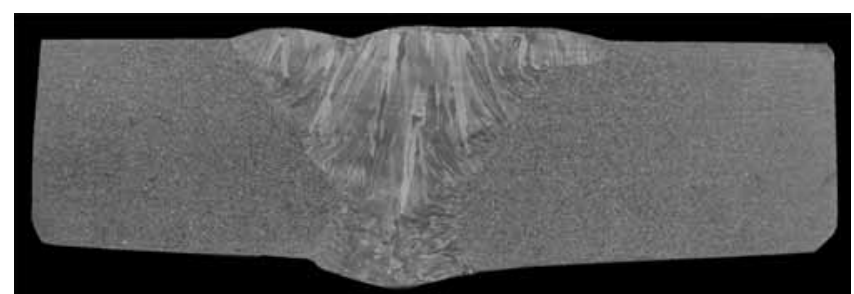

Rys. 10. Złącze doczołowe obwodowe rury $ø 38 \times 8,8 \mathrm{~mm}$ ze stali Tempaloy A-3 wykonane metodą TIG; trawienie: Nital; pow. $2 x$; poziom jakości: $B$

Fig. 10. TIG welded circumferential butt weld of $\varnothing 38 \times 8,8 \mathrm{~mm}$ Tempaloy A-3 steel, Etching: Nital, magn. 2x, quality level B

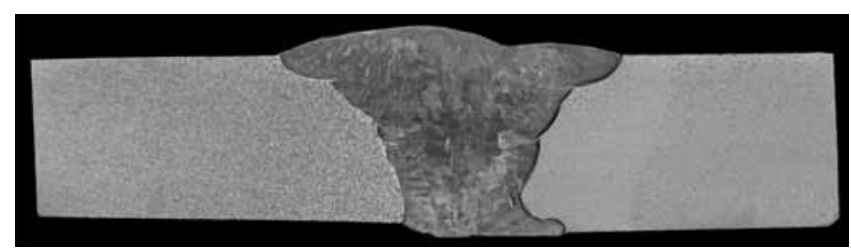

Rys. 11. Złącze różnoimienne ze stali Tempaloy A-3 oraz T91 wykonane metodą TIG spoiwem Metrode EPRI87; trawienie: Nital; pow. 2x; poziom jakości: $B$

Fig. 11. TIG welded dissimilar circumferential butt weld of $ø 38 \times 8,8 \mathrm{~mm}$ Tempaloy A-3 and T91 steel with Metrode EPRI87 as filler metal, Etching: Nital, magn. 2x, quality level $B$

\section{Wyniki badań metalograficznych makroskopowych}

Badania wykonano zgodnie z PN-EN 1321 [16]. Jako kryterium oceny przyjęto poziom jakości B wg PN-EN ISO 5817, które zostało spełnione dla złączy próbnych. Na rysunku 10 przedstawiono wynik badań makroskopowych w postaci zdjęcia makrostruktury złącza doczołowego obwodowego ze stali Tempaloy A-3 wykonanego metodą TIG.

Na rysunku 11 przedstawiono zdjęcie makroskopowe złącza różnoimiennego ze stali Tempaloy A-3 oraz T91.

\section{Wyniki badań metalograficznych mikroskopowych}

Badania mikroskopowe wykonano wg PN-EN 1321. Wyniki badań nie wykazały żadnych niezgodności spawalniczych w skali mikro i potwierdziły właściwą mikrostrukturę we wszystkich strefach złączy doczołowych zarówno ze stali Tempaloy A-3, jak również połączenia mieszanego Tempaloy A-3 i T91. W tablicach VI i VII przedstawiono wyniki badań mikroskopowych w postaci zdjęć i opisów struktur występujących w charakterystycznych strefach złącza spawanego.

Tablica VI. Wyniki badań mikroskopowych złącza doczołowego obwodowego ze stali Tempaloy A-3

Table VI. Microscope observation results for circumferential butt weld of Tempaloy A-3

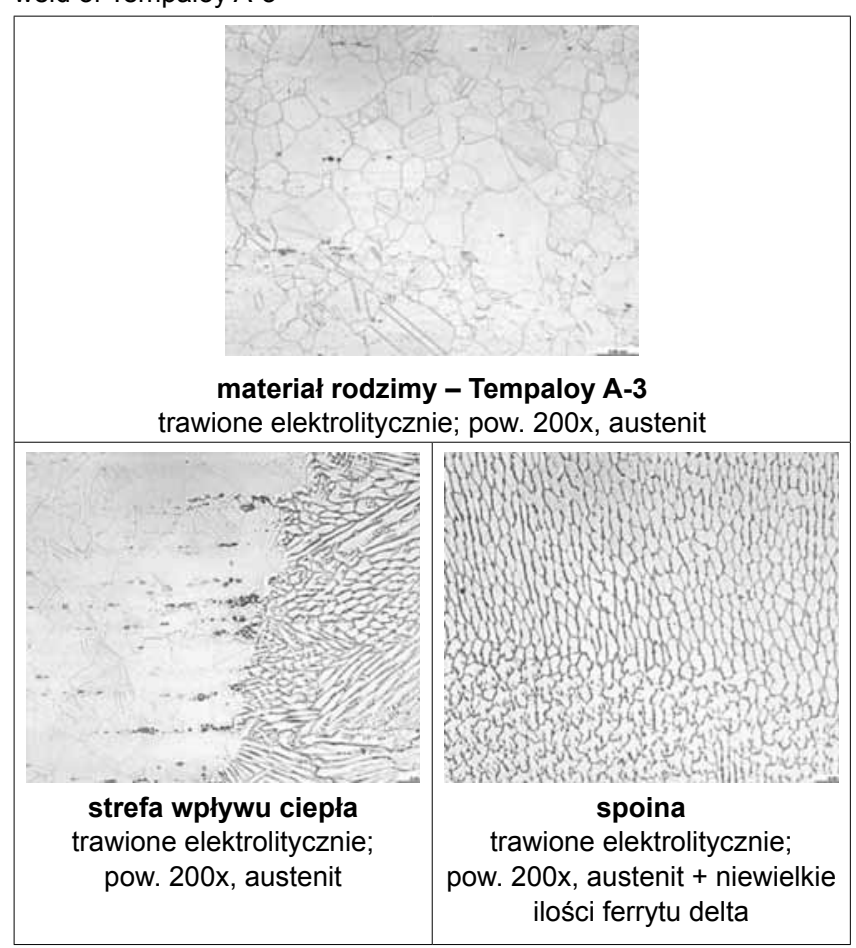


Tablica VII. Wyniki badań mikroskopowych złącza różnoimiennego ze stali Tempaloy A-3 i T91

Table VII. Microscope observation results for dissimilar circumferential butt weld of Tempaloy A-3 and T91 steel

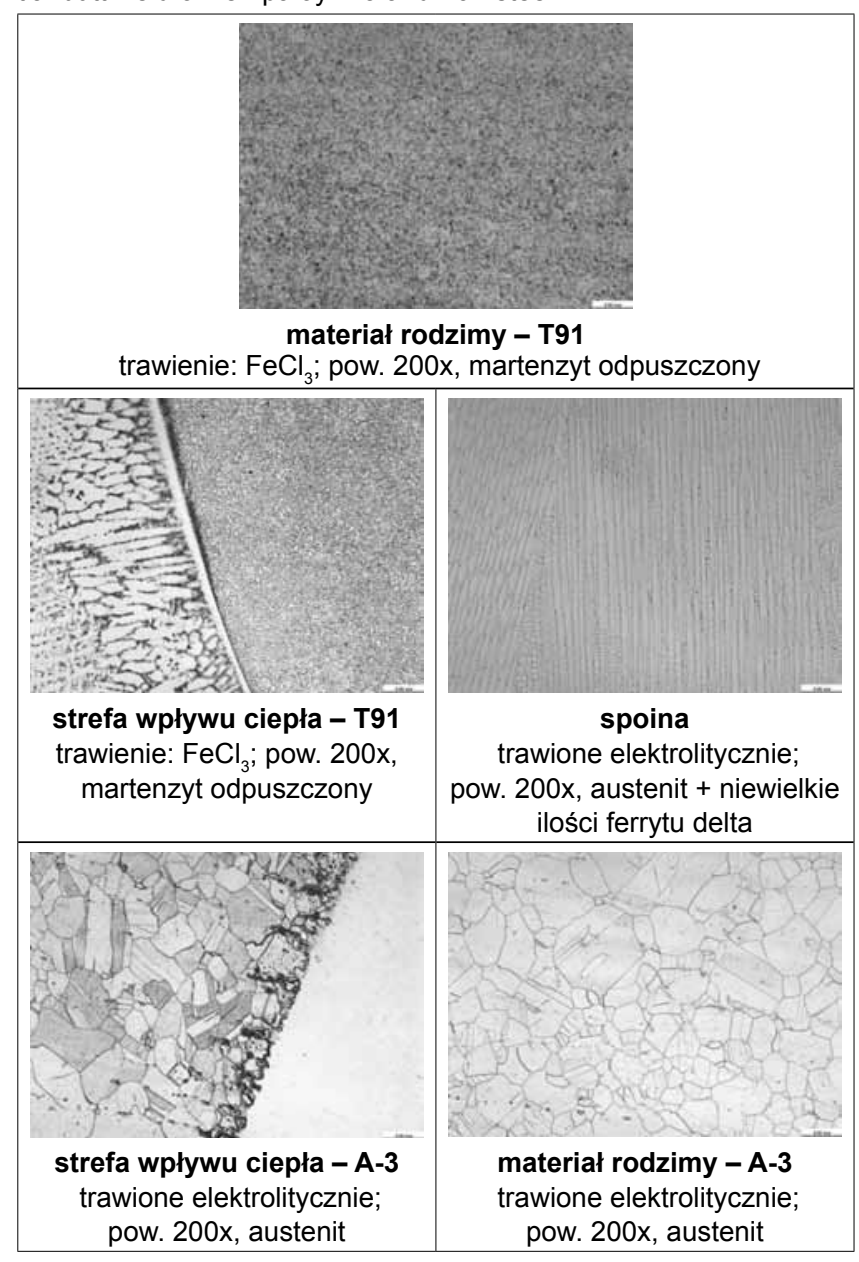

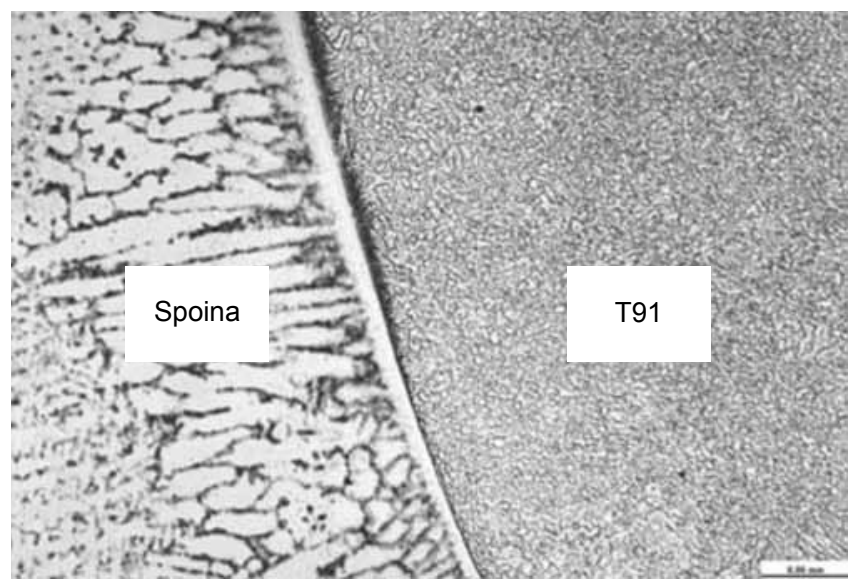

Rys. 12. Strefa przejścia pomiędzy spoiną EPRI87 a stalą T91 Fig. 12. Weld interface between EPRI 87 weld and T91 steel

Na rysunku 12 zamieszczono zdjęcie mikroskopowe strefy przejścia pomiędzy spoiną a stalą T91. Zastosowanie spoiwa EPRI 87 pozwoliło na uzyskanie bardzo wąskiej strefy odwęglonej w porównaniu do spoiw takich jak np. 309L lub ERNiCrMo-3. Wąska strefa odwęglona pozwala na zmniejszenie „strefy osłabionej" materiału ferrytycznego/martenzytycznego. Mniejsza rozszerzalność cieplna spoiwa EPRI 87 niż np. IN617 niweluje naprężenia powstające podczas eksploatacji pomiędzy spoiną a materiałami spawanymi, co również bezpośrednio wpływa na trwałość złącza.

\section{Wnioski}

Na podstawie badań sformułowano następujące wnioski:

- Złącze doczołowe wykonane z rur o średnicy $38 \mathrm{~mm}$ ze stali Tempaloy A-3 oraz połączenie mieszane stali Tempaloy A-3 ze stalą T91 spawane metodą TIG w pozycji PF odznaczają się wysoką jakością, co zostało potwierdzone przez wyniki badań nieniszczących i niszczących.

- Problemem wydaje się dostępność materiału dodatkowego do spawania stali Tempaloy A-3, który jest produkowany tylko w Japonii w postaci drutu litego (brak prętów TIG).
- Zastosowanie spoiwa Metrode EPRI87 pozwoliło uzyskać bardzo dobre wyniki spawanego złącza różnoimiennego, a badania mikroskopowe potwierdziły brak występowania mikroniezgodności spawalniczych. Strefa odwęglona/nawęglona jest bardzo wąska, co korzystnie wpływa na właściwości eksploatacyjne złącza.

- Planowane badania mikroskopowe oraz próby pełzania umożliwią dokładniejszą analizę wykonanych połączeń oraz ich przydatności na skalę przemysłową.

\section{Literatura}

[1] M. Urzynicok, K. Kwieciński, J. Słania: Właściwości złączy spawanych ze stali bainitycznej 7CrMoVTiB10-10 (T24) stosowanej w elektrowniach pracujących przy parametrach nadkrytycznych. Biuletyn Instytutu Spawalnictwa, 6/2009.
[2] M. Urzynicok, K. Kwieciński, M. Szubryt: Doświadczenia przy wykonywaniu połączeń doczołowych ze stali martenzytycznej VM12-SHC. Przegląd Spawalnictwa, 11/2009. 
[3] M. Urzynicok, K. Kwieciński, M. Szubryt, J. Słania: Application of new GMAW welding methods used in prefabrication of P92 (X10CrWMoVNb9-2) pipe butt welds. 9th Liege Conference on Materials for Advanced Power Engineering, September 27th - 29th, Liege, Belgium, 2010.

[4] K. Kwieciński, M. Urzynicok, M. Łomozik: Practical experience with welding new generation steel PB2 grade assigned for power industry. Archives of metallurgy and materials, Vol. 56, Issue 1, 2011.

[5] Caminada S., Cumino G., Cipolla L., Venditti D., Di Gianfrancesco A., Minami Y., Ono T.: Creep properties and microstructural evolution of austenitic TEMPALOY steels. International Journal of Pressure Vessels and Piping 87 (2010).

[6] Schingledecker J.: Update on EPRI P87 Filler Metal. Boiler Reliability Interest Group, Baltimore 22.04.2010.

[7] PN-EN ISO 5817:2009 Spawanie. Złącza spawane ze stali, niklu, tytanu i ich stopów (z wyjątkiem spawanych wiązką). Poziomy jakości według niezgodności spawalniczych.

[8] PN-EN 10216-2+A2:2009 Rury stalowe bez szwu do zastosowań ciśnieniowych. Warunki techniczne dostawy. Część 2: Rury ze stali niestopowych i stopowych z określonymi własnościami w temperaturze podwyższonej.
[9] PN-EN ISO 6892-1:2010 Metale. Próba rozciągania. Część 1: Metoda badania w temperaturze pokojowej.

[10] PN-EN ISO 4136:2011 Badania niszczące złączy spawanych metali - Próba rozciagania próbek poprzecznych.

[11] PN-EN 12952-6:2011 Kotły wodnorurowe i urządzenia pomocnicze. Część 6: Badania podczas wytwarzania. Sporządzanie dokumentacji i znakowanie części ciśnieniowych kotłów.

[12] PN-EN ISO 9016:2011 Badania niszczące złączy spawanych metali. Badanie udarności. Usytuowanie próbek, kierunek karbu i badanie.

[13] PN-EN ISO 148-1:2010 Metale. Próba udarności sposobem Charpy'ego. Część 1: Metoda badania.

[14] PN-EN ISO 15614-1:2008/A1:2010 Specyfikacja i kwalifikowanie technologii spawania metali. Badanie technologii spawania. Część 1: Spawanie łukowe i gazowe stali oraz spawanie łukowe niklu i stopów niklu.

[15] PN-EN ISO 5173:2010 Badania niszczące spoin w materiałach metalowych - Badanie na zginanie.

[16] PN-EN 1321:2000 Spawalnictwo. Badania niszczące metalowych złączy spawanych. Badania makroskopowe i mikroskopowe złączy spawanych.

\section{Podziękowania}

Autorzy pragną podziękować firmie Tenaris Dalmine za udostępnienie stali Tempaloy A-3, firmie Metrode za dostarczenie prętów EPRI 87 oraz firmie ZELKOT w Koszęcinie za wykonanie złączy spawanych.

\section{Sekcja Spawalnicza}

\section{Zebranie Sekcji Spawalniczej SIMP}

W dniu 7 marca 2012 r. w gmachu NOT w Warszawie odbyło się posiedzenie Związku Głównego Sekcji Spawalniczej SIMP. Program obrad zawierał: podsumowanie działalności Sekcji Spawalniczej w 2011 r., omówienie planów poszczególnych Oddziałów Sekcji na 2012 r., omówienie kalendarium spawalniczych imprez naukowo-technicznych na $2011 \mathrm{r}$. oraz stanu ich przygotowań, rozpatrzenie wniosków o odznaczenia Medalem im. Stanisława Olszewskiego w 2012 r. oraz sprawy bieżące.

Zebranie otworzył Prezes dr inż. Jan Plewniak, który omówił formy zaangażowania Sekcji w 2011 r., podkreślając jej najlepszą pracę w Oddziale Dolnośląskim, któremu przewodniczy dr hab. inż. Zbigniew Mirski, prof. PWr.

W minionym roku największymi organizowanymi lub współorganizowanymi przez Sekcję imprezami technicznymi były: XVII Naukowo-Techniczna Krajowa Konferencja Spawalnicza „Postęp, innowacje i wymagania jakościowe procesów spajania", Międzyzdroje 31.05-02.06.2011 r., X Szczecińskie Seminarium Spawalnicze, 02.06.2011 r., XV Gdańskie Spotkanie Spawalników Wybrzeża, 8 września 2011 r., I Międzynarodowa Konferencja Naukowo-Techniczna "Napawanie - postęp i zastosowania”, Wrocław, 19-21.09.2011 r. oraz 53 Krajowa Naukowo-Techniczna Konferencja Spawalnicza „Nowe kierunki w procesach spajania i cięcia metali”, Poznań, 12-14.10.2011 r. W sumie w różnego rodzaju imprezach technicznych uczestniczyło 2841 uczestników zrzeszonych w 13 oddziałach sekcji.

Sekcja zanotowała również $10 \%$ przyrost liczbowy swoich członków. Prezes przedstawił kalendarium wybranych imprez naukowotechnicznych "Spawalnictwo 2012".

W planach na 2012 rok sa m.in. konferencje i seminaria organizowane lub współorganizowane przez Sekcję Spawalniczą SIMP badź Polskie Towarzystwo Spawalnicze: XVIII Konferencja Spawalnicza „Spawanie w energetyce” 24-26.04.2012 r., Jarnołtówek, XVIII Naukowo-Techniczna Krajowa Konferencja w Międzyzdrojach organizowana przez Zachodniopomorską Sekcję Spawalniczą, Międzynarodowe Targi w Poznaniu, czerwiec 2012 r., Mazurskie Spotkanie Spawalników (LINDE), Ruciane Nida 13-14.06.2012 r., Wrocławskie Seminarium Spawalników (LINDE), 20.06.2012 r., XI Szczecińskie Seminarium Spawalnicze (LINDE), 06.09.2012 r., XVI Gdańskie Spotkanie Spawalników (LINDE), 13.09.2012 r., III Międzynarodowa Konferencja Naukowo-Techniczna "Natryskiwanie cieplne - Technologia XXI wieku", 19-21.09.2012 r., Kielce/Korytnica, 54 Krajowa Spawalnicza „Spawalnictwo, osiagnięcia - potrzeby - wyzwania”, 16-18.10.2012 r., Sosnowiec i Expo WELDING. Odbędą się również kolejne seminaria i spotkania spawalników Wybrzeża w Gdańsku i w Szczecinie, wzbogacone o pokazy praktyczne, udział firm sponsorskich i inne branżowe atrakcje.

Rozpatrzono kandydatury: Romana Andrzejczaka, Bogusława Olecha, Norberta Pikora, Adama Matulki i Jana Kielczyka do wyróżnienia Medalem im. Stanisława Olszewskiego. W wyniku głosowania wymienionym osobom postanowiono nadać to szczególne wyróżnienie.

W sprawach bieżacych postanowiono wznowić korespondencje z Narodowym Bankiem Polskim w sprawie emisji 2 i 10 zł monet okolicznościowych poświęconych sylwetkom Stanisława Olszewskiego i Stefana Bryły.

Uzgodniono, że akcję promocyjną Rejestru Spawalników Polskich będą prowadzić oddziały sekcji, tak by tej cennej inicjatywie nadać szerszy status.

Dr inż. Kwiryn Wojsyk, dr inż. Jan Plewniak 